\title{
Legal Principles, Problems and Procedures for Providing Service land uses and Per Capita in Urban and Rural Development Plans in Iran
}

\author{
Masoud Masoumi \\ Director of Department of Urban and Architecture of Tehran - Iran Governorate \\ Master's Degree in Urban and Regional Planning from the Faculty of Architecture and Urban planning, \\ Shahid Beheshti University, Tehran, Iran \\ www.m-masoumi.com \\ mmasoumi33@yahoo.com
}

\begin{abstract}
Designing and building residential applications in cities and villages is meaningless without providing service infrastructure and utilities and per capita. Because families and residents living in a residential area need urgently and continuously access to and use of a variety of service land uses, including green spaces, educational, health care, and so on. These uses are often not profitable, and the private sector is not particularly interested in buying and investing for them. How to provide services is one of the main problems in the planning and implementation of urban and rural development plans in Iran. In Iran, there are two state organization to assign lands (Ministry of Agriculture and Ministry of Roads and Urban Planning).
\end{abstract}

These ministries hold « Natural Resource Land» and «Urban Lands », but do not have the necessary efforts or have the land available to provide adequate service land uses. Urban land ownership in Iran is $\mathbf{9 5 \%}$ private, and inevitably the required service land is purchased by the custodian ministry and the cost of constructing the facilities, and ultimately resulting in the creation of a service land uses. Lack of financial resources, neglect of the problem, ambiguity in the laws, urban and rural management problems are among the most problematic factors and the lack of satisfactory maintenance of service land uses and per capita.

In the period prior to the victory of the Islamic Revolution (February 22, 1978), very few cities and villages in Iran enjoyed urban development plans. The provision of service land uses was carried out by the ministry and the Provincial Trustee as part of the site. The Pahlavi state - especially in the last decade before the collapse - was financially capable, but did not have the necessary resources to supply infrastructure (drinking water, sewage, electricity, gas and telephone) and other services such as hospitals and educational centers in the villages. Although there was a shortage in cities, but the situation in the cities especially in the provincial capital were better than villages.

After the victory of the Islamic Revolution, the development of urban, rural and agricultural development was one of the priorities of the Islamic Republic of Iran. A government organization - called the "Constructive Jihad" was established and one of its duties was rural civilization. A bit later, the 8-year war between Iran and Iraq was started. The war was a slowdown for building construction. Lack of financial resources has been added to previous problems and nowadays both urban and rural communities are struggling. After the victory of the Islamic Revolution, several laws have been passed so far to accelerate and facilitate the ownership of land services and the creation of per capita. But these rules are often inadequate, parallel, or ambiguous.

Keywords: Per Capita, Land Use, Service Land Uses, Financing, Residential Land Use, Comprehensive Plan

\section{Introduction}

< The City Council for Urbanism and Architecture of Iran〉>, as the most specialized and highest decisionmaking authority in the field of urban planning and architecture of Iran approved the per capita rate and types of urban usage, for the first time in 2010. Until this date, there were no uniform and comprehensive standards for land use planning in Iran. And urban planning consultants are using standards and methods to formulate urban development plans. According to the Decree of the Supreme Council on Urban and Architecture of Iran dated 2010-05-31, urban uses are classified into 20 types: Residential, transit, industrial, agricultural, service (including: educational, medical, green space, administrative, commercial, sanitary, cultural, religious, urban facilities, military, transportation and warehouse etc.) (urban council and Architecture of Iran, 833-845). According to this Decree, a four-level demographic classification for cities is presented. 
A) Cities with a population of less than 50 thousand people

B) 50,000 to 250,000 people

C) 250 thousand to one million people

D) cities with a population of more than one million people.

Then it is specified for each person at each per capita level. As an example, the per capita residential use for each person in a city with a population of less than 50 thousand people is equivalent to 《 less than 50 square meters 〉 > The same per capita for a city of more than one million people is equivalent to « less than 25 square meters 〉 > Also, the per capita of sports use for each person in a city with a population of less than 50 thousand people is equivalent to $\langle<1$ to $1.5 \mathrm{~m}$ 〉 . Per capita of sports use has been set for a city with a population of more than one million as $<<1.2-2$ square meters $>$. For other uses, figures have been determined as per capita. (Iran's Urbanism and Architecture Council 846- 849)

\section{Problem Statement}

Lack of Service land uses and Per Capita: The amount of per capita at the time of establishing urban development plans is a criterion for the design and planning of urban activities. The plans are communicated by a supreme authority (governor of each province). But after several years, residential applications are often constructed and resettled, but service land uses are limited to a very limited extent. According to Iran's Urbanism and Architecture Council standards, the total service land uses required per citizen vary between 75 and 110 square meters in cities with different populations that must be realized. But in none of the cities, such a level of service has not been created.

Increasing the accessibility and distribution gap of service land uses: the disparity of services uses with residential land uses actually leads to an increase in the distance of the access range, the unequal distribution of service land uses in neighborhoods, denial of access to services and lower quality of life, resulting in an unfavorable face of urban and rural development. These conditions have not been approved in any way by the expected urban development plan.

\section{The Main Objectives of This Article}

This article follows the following objectives:

- Review of laws related to the provision of per capita and services in urban and rural development plans in Iran.

- A brief analysis of ambiguities, shortcomings and contradictions in legal material.

- Suggestion to solve the problems.

\section{A Review of Legal Material and Land-Use Legislation for Service Creation}

Here are some legal issues related to the provision of services:

\section{1) Unplanned period (1978 to 1988)}

After the victory of the Islamic Revolution (1978) until 1988, no five-year plan was drafted and ratified in Iran. Therefore, this term has been named as "unplanned course" in the term "urban planners".

\section{2) Rules of the Five-Year Plan of Economic, Social and Cultural Development of the Islamic Republic of} Iran.

After 1988, the preparation and approval of the programs began with a delay of ten years. These programs are named as the "Law on Economic, Social and Cultural Development". The term is five years and are approved by the Islamic Consultative Assembly. After the adoption, they are considered as necessary laws and regulations. For a brief summary, look at the legal provisions of the above programs on how to procure, procure and execute service land uses:

\subsection{The First Plan of Economic, Social and Cultural Development (1989-1993):}

In the note 10 below, the following article states:

A) The Ministry of Housing and Urban Planning (Municipal Land Organization) is required to use all educational, cultural and service land in all cities of the country and in the form of approved urban plans for the construction and development of schools, cultural and artistic centers, sports and health centers, training and after-ownership services, free of charge to related organizations, and may, in materials subject to land tenure, pay the relevant amount on the price of other transferable housing units and getting money in all the cities and getting the relevant buyers or giving away the land to the property.

B) The municipalities are obliged to introduce the land listed in clause (a) of this note on the basis of comprehensive, conductive and detailed plans approved by the relevant organizations immediately; and, during the execution of the said plans, the relevant organizations shall grant the building permit without complying with the issuance procedure for construction permit and only by the notice the area and floor. 


\section{2-2) Law of the Second Program of Economic, Social and Cultural Development (1995-1999):}

Note (49) below to the unified article states: "The Ministry of Defense and the support of the armed forces of the Islamic Republic of Iran and the armed forces of the country are required, after obtaining permission from the Supreme Leader and the commander-in-chief, to sell the arenas of the garrisons and other places that they have owned or licensed (after proof of ownership) to enter the scope of municipal services through bidding".

Note (68) under the single article: "The Ministry of Housing and Urban Development is required to acquire lands with sports use throughout the country at a fair price for the day and give it free to the Physical Education Organization. The required credit for this note is considered annually in the budget plan".

Note (84) below of the article states:

A) "The Ministry of Housing and Urban Planning is required to use land for educational, cultural and service purposes in the form of approved urban plans in accordance with the law of the program in all cities of the country at fair price of the day and according to the relevant laws, it is purchased and acquired for the purpose of the construction and development of schools and cultural and artistic centers, educational, sports, health, medical, rehabilitation, support and training and employment - Professional technical training of fire stations, garbage collection, pumping and sewage with the regional price of 1993 to the related organizations".

B) The municipalities are obliged to immediately notify the relevant authorities of the land listed in clause (a) of this note on the basis of comprehensive, detailed plans, and, when executing such plans, by the relevant authorities, authorize the construction of the site without complying with the procedure and issue a building permit and only issue the floor and area. In any case, it is essential to observe the technical regulations and urban planning regulations.

C) "Appliances having cultural, artistic, sporting, sanitary, medical, educational, administrative and military centers, and modified according to approved urban plans, are authorized to sell the centers in accordance with applicable laws through auctions. To pay the proceeds to the treasury in its entirety and to replace it, to complete and renovate similar centers, and to maintain in accordance with the rules of old funds".

\section{2-3) - Law of the Third Plan of Economic, Social and Cultural Development (2000-2004):}

Article 141 of the law:

< A. the Ministry of Housing and Urban Planning is authorized to provide for the part of the funds required for the implementation of the law to encourage the construction and supply of residential units for rent or lease on condition that the land is owned by the city at the price of the day and it sells at a bargain price or which will not be lower than the issued price.

B. The Ministry of Housing and Urban Planning is authorized to assign land with a training, cultural, sporting and religious uses to the regional price during the third development plan 〉 >.

Article 161 of the Law: « B. The provision of suitable land for the construction of cinemas and cultural complexes in new cities will be done by the Ministry of Housing and Urban Development and will be the responsibility of municipalities in urban development plans $>>$.

Article 163 of the law: < B- The Ministry of Housing and Urban Planning and municipalities are obliged to create suitable lands for the construction of mosques and Basij resistance bases in all new settlements and, after being prepared without a fee, to provide applicants for the construction of mosques and basij resistance bases and land prices at the expense of land preparation. > >

E) The municipalities and the forestry organization are obligated to create appropriate mosque or prayer houses in order to allocate appropriate space in national and public parks. > >

Article 177 of the law: « The Ministry of Defense and the support of the armed forces of the Islamic Republic of Iran and the armed forces of the country are required, after obtaining permission from the Supreme Commanderin-Chief, to sell the arenas and lords of the garrisons and other places that are in possession of them. And within the scope of urban services (after proof of ownership) and change the use and division through bidding. > >

\section{2-4) The Law of the Fourth Program of Economic, Social and Cultural Development (2005-2009):}

Part $\langle\langle\mathrm{D}\rangle\rangle$ from clause (3) below Article 117 of the Fourth Plan Law: Ministry of Housing and Urban Planning and municipalities are required to provide education, sports and cultural services in the country when issuing permits for the construction of cities, towns, plan implementers will be responsible for the provision and construction of these spaces in accordance with the residential infrastructure. > > 
Section < $\langle\mathrm{H}\rangle\rangle$ in accordance with Clause (3) below (117) of the Law of the Fourth Plan: < The Ministry of Housing and Urban Planning is required to purchase lands using sporting equipment throughout the country in coordination with the Physical Education Organization and assign the following: A) Free of charge to the Physical Education Organization and the company for the development and maintenance of sports facilities in the country. B) at the expense of the private and cooperative sector. > >

\section{2-5) Law On the Fifth Program of Economic, Social and Cultural Development (2011-2015). This Law Was Later Extended to 2016.}

In the fifth law, no provision was made for the provision of service land uses.

\section{2-6) Law of the Sixth Program of Economic, Social and Cultural Development (2017-2021)}

Article (111) of the Law of the Sixth Program: Article (111) of the Law of the Sixth Program states: < The Ministry of Agricultural Jihad is obligated, with the exception of the construction of and development of sports grounds, sports grounds, non-agricultural national lands outside the city limits and the area of the villages. The lands located in the quaternary areas of the environment, which are required by the state-owned sector, with the approval of the Ministry of Sports and Youth at the price of the transaction value announced by the Ministry of Economic Affairs and Finance, with due process of law to the non-governmental sector and cooperative with the priority of the sacrificial cooperatives. Change in the use of these lands is prohibited. The proceeds from the execution of this decree are deposited into the treasury. > >

\section{3) The Laws That Provide Free Land Ownership to Landlords and Service land uses Emphasize:}

3-1) Note (6) under the Law on the Procedure for the Calculation of Buildings, Properties and Land Required by the Municipalities - Adopted on 1991-11-4 < For providing the maintenance of the buildings, properties and legal lands of the people who are in Authorities of municipalities, the government is obliged to allocate $10 \%$ of the leased land and housing units to the municipalities for delivery to the municipalities after the agreement between the owners and the municipalities. > >

3-2) Note (4) under the Law on Determining the Status of Real Estate in Government Plans and Municipalities was approved on May 28, 1968 < In cases where the provision of land for alteration within the permitted limits for segmentation and construction of the building is not possible and the development of this area is required in accordance with the approved urban development plans approved by the law enforcement agencies. These references can be made against the consent of the landowners to use the benefits of entering the development and the city in addition to fulfilling the obligations related to the development and preparation of land and assigning the necessary lands for facilities and public services up to $20 \%$ of Their lands for the provision and replacement of lands in thematic plans of this law as well as lands receive urban renewal and urban renovation plans free of charge. >>

3-3) Note 3 below to the unified article of the amendment article (101), which was approved by the Guardian Council on 2011-4-27, with the following deductions for passages and service land uses: < < In the lands with an area of more than five hundred meters Square, which has the document, is the municipality to provide per capita public space and services up to $25 \%$ and to provide the lands necessary for the construction of public streets and townships due to the division and division of these lands in accordance with a detailed and detailed plan for value added Created from the separation operation for the owner, receives up to to $25 \%$ of the remaining land. The municipality is allowed to agree with the owner of the shareholder on the basis of the price of land for the day according to the official expert opinion of the court. > >

3-4) Article (101) of the Municipal Law: "Article (101) of the Municipality Law was adopted in 1955. The article referred to the law: "The public streets and public Alleys created by the separation of the land belong to the municipality and the municipality will pay no compensation to the owner in any way." (Mansour, Jahangir, 110) This article was amended in 2011. According to its note 3: < In the area with more than 500 square meters of land with a document, the municipality is responsible for providing per capita public space and services up to $25 \%$ and for the provision of lands for public buildings streets of the city, due to the separation and division of this land receives up to $25 \%$ of the remainder in accordance with the comprehensive plan, taking into account the added value created by the separation operation for the owner. The municipality is authorized by the owner's agreement to receive the aforementioned land price according to the price of the land, according to the opinion of the official expert of the judiciary $>>$.

According to Note (4) also: < All land from Note (3) and public passageways and service land which is caused by the division, and issuance of the ownership certificate, belongs to the municipality. The municipality will pay nothing to the owner of the property in return for it. In cases where it is not possible to provide different types of per capita, manure and passageways from the ground, the municipality may, by ratification of the Islamic city of the city, receive the equivalent of its price at the expert rate. > > 


\section{4) Supreme Council of Urban Development and Architecture of Iran.}

Also, the High Council for Urbanism and Architecture of Iran in the comprehensive plan of 23 cities of Tehran province, including in Note (10) below (21) protection of valuable residential and non-residential buildings, pages 13 and 14 of the regulations and regulations of the master plan approved dated 25-04-2011 and 22 other cities of Tehran province: < The construction in that part of the land that has been added to the proposed comprehensive plan to the province of Tehran and the cities included in it is subject to the transfer of at least $70 \%$ of the land in the form of Integrated to the municipality for free to provide the public services needed by the city > >. Also, according to Clause (2) of page 3 of the Terms and Conditions of the master plan, < < the issuance of building permits, on vacant lands and specially built tents with disparate urban uses (such as repair shops, garrisons, etc.) with an area of over 5000 square meters (One plaque or several plates) is subject to the provision of services in the framework of the comprehensive plan and after approval by the Commission under Article 5 > >.

5) Laws that focus on land acquisition through pricing and purchasing by the trusted ministry: The titles of some laws that deal with the purchase and land use of a service land uses are as follows:

5-1) Legislative Bill on the Sale of Land and Properties Required by the Government and Municipalities Adopted on 1979-11-24

5-2) The Law on Calendars (Pricing) of Buildings, Properties and Land Required by the Municipalities Adopted on 1991-11-19

5-3) Legislative Bill on the Acquisition of Land and Real Estate for the Implementation of Public, Developmental and Military Programs of the State - Adopted 1980-02-06

5-4) The Law on the Determination of the Status of Real Estate in State Plans and Municipalities - Adopted on 20-11-1988.

\section{6) The Agreement Between the Municipality and The Owners:}

In some cases, municipalities also use their management authority to select land for city integration or change of ownership and in different ways compel landowners to transfer part of the land to the municipality for service land uses. This rule applies to lands within the area equal to $50 \%$ of the owner's share and $50 \%$ of the municipality's share and with regard to land adherence to the city, the $70 \%$ share of the municipality's share and $30 \%$ of the owner's share are commonly used. At the time of writing, the agreement cites Articles 190 and 210 of the Civil Code. This article allows individuals and legal entities to agree. Of course, a deal is based on Islamic law.

\section{7) The Laws That Oblige the State to Assign Land for Services:}

7-1) - In the < L Land Law of the City - approved 1987-09-13 > > and relevant regulations, the state (Ministry of Roads and Urban Planning) is obliged to give land for services. Of course, these assignments are mainly paid for land or by retaining state ownership (on behalf of the Ministry of Roads and Urban Planning) merely to seize the equipment. Of course, in a limited number of articles of this law, including Note 4 below, Article 10, the free allocation of land to departments and some organizations to the extent of the administrative and utility needs for free. (Mansour, Jahangir, 1543)

7-2) In accordance with current laws, the Natural Resources Office (this department is under the Ministry of Agricultural Jihad) is authorized to provide natural and legal persons and ministries with natural resources as natural resources for the establishment of service land uses and facilities and equipment and give it for cultivation and gardening. The assignment of these lands requires special administrative formalities.

\section{8) Judgments of the Administrative Justice Court:}

< ( The Administrative Justice Tribunal > > is a subset of the Judiciary of Iran and is, in fact, a judicial authority. The duty to deal with the government's demands on the government, the government over people and people over the government. Based on numerous opinions issued by this court, any extraction of land from owners that is contrary to the law is illegal. The Administrative Court of Justice has repeatedly declared illegal and illegitimate resolutions of the Supreme Council on Urbanism and Architecture of Iran about various cities. However, the Supreme Council, despite the Court's opinions, continues to insist on enforcing its resolutions and has made difficulties for owners and citizens.

\section{9) Comments by the Guardian Council:}

《 The Guardian Council of the Constitution > > is a council whose duties are to review and conform to the laws passed by the Islamic Consultative Assembly with the Constitution. In several theories, including in the notion No. 96/102/3441 on 3-12-2017 concerning the city of Shahriyar, \& < taking the lands of individuals free of charge and without their consent and without legal authority is contrary to Islamic law $>>$. 


\section{Some Basic Challenges in Providing Services}

Despite the laws mentioned, most owners did not permit and refrain from assigning lands and service quotas in different ways. Obviously, under such circumstances, the calculations of the approval authorities of the plans of the city council and the architecture of Iran regarding the operation and implementation of the comprehensive plan will face limited constraints and in the long run, cities will face a lack of service land uses. Some of the challenges below are addressed in the following paragraphs.

- Continued Failure to Provide Services Lands in Five-Year Programs: A five-year study shows that it has focused on one or a limited number of applications in a five-year plan, but there has been no mention of it in the next program. It seems that the problems of citizens and the lack of service land uses for that user has been resolved.

- Lack of Compliance Assessment System: At the end of the program, no evaluation has been made to measure the extent of the implementation of a legal provision related to the provision of services. The writer's follow-up of this article shows that in some cases in a province, enforcement of a legal act has been delayed and no financial credentials or effective measures have been taken to enforce the law.

- Focusing on Some Services and Neglecting Other Services: Studying the rules of the sixth program above shows that at some point, some uses such as landfill, refinery, public parking is not considered, and there are always a limited number of uses such as sports, education has been at the center of attention.

- The Right of Ownership to Landowners in The Area of Separation and Annexation of Land to The City: 〈 in Article 101 of the Municipality Law〉 > and 〈(Note 4) under the Law on Determining the Status of Real Estate in State and Municipal Plans > >, the legislator has emphasized the will of the landowner to join the land in the city or the owner's request for land separation. This emphasis is to the extent that it is impossible to assign the land without the owner's will. And, in the end, provision of service land uses with an encountered problem and urban management and urban planning should seek to obtain landowners' consent to join the city. While in Iran, as soon as the land is annexed or separated, significant added value is created and substantial profits are generated between two and 20 times for the owner, and often no profit is generated for urban management and the general citizen.

- Ambiguity and Interpretation of the Rules: The rules and numbers contained in them are not transparent. They are often interpreted and used incorrectly. As a result, legal materials are not executed correctly. Some of the numbers are aggregated and some only consider one of the legal rules.

- Comprehensive Rules: The rules are not comprehensive and impede. And do not respond to different modes and many demands of urban management and urban planners. For example: « The Law on the Determination of the Status of Real Estate in Government Plans and Municipalities - approved on 20-11-1988, has emphasized that the relevant consumer trustee ministry must take ownership of land. If more than 5 years have elapsed since the announcement of the plan and the ministry failed to purchase land, the municipality will be obliged to issue a building permit. But it has never been mentioned in terms of the area of the building and the type of use of the building. It is also not known when the 5-year period starts? If we assume that the rules are like puzzle pieces, then the rules often coincide when there are some common rules or there is a significant gap between them!! That is an escape for some profitable people.

- Lack of Attention to The Village: In 1956, about a third of the population of Iran live in the villages and two thirds in the cities. According to the 2016 census, this ratio has been reversed. About two thirds of the population of Iran resides in cities and one third in rural areas. In $95 \%$ of the legal material and the above mentioned references, the "city" have always been referred and have not been addressed to the rural community. It seems that one third of the society is not subject to these rules and there is no way to provide them with services.

- Lack of Financial Resources: Although several laws have been approved for the purchase and possession of land with a service land uses, there has never been enough financial and funding for land purchase. In the event of funding, there is also a very long and tedious administrative bureaucracy that causes the owners to be distressed, or land ownership is delayed even after the end of the horizons of the comprehensive urban plan.

\section{Conclusion and Findings:}

The suggestion for this article is to:

1) The abolition of illegitimate approvals of the Supreme Council of Urbanism and Architecture of Iran for the free reception of citizens from the land. Integrating and rewriting current laws in a way that is transparent, comprehensive and responsive to the needs of citizens. The rules do not contradict each other and cover all the different issues and algorithms.

2) The required lands of services should be tailored to the standards of the Supreme Council for Urbanism and Architecture of Iran, and the economic and social conditions of each city and village, as well as the amount of population loading in each registry plaque, while meeting the needs of the neighborhood and urban areas, and from the insertion and approval of cultivars Vague, dogmatic and tangible rules in the rules. 
3) Any land delivery to the city boundaries or the division of land and the use of land should be in accordance with the owner's rights and urban management. These measures will actually lead to the creation of a multiplier value for land. Value added should not only be understood by the owner, but must also be of benefit to the urban management and the general citizen. The benefits can be a share of the land allocated for service land uses, or the Rial value of the portion of the land held on a separate account and allocated solely for the purchase of service land.

4) The creation of a joint property bank between municipalities and other ministries can lead to the exchange of land between different municipalities and ministries. Minority should be avoided and the land was given priority to the ministry or the municipality and the neighborhood in a flexible manner through the joint property bank.

\section{References}

[1] High Council for Urbanism and Architecture of Iran, 2012, Assembly of Supreme Council of Urban and Architecture of Iran - From the beginning of the establishment until the end of 2011, Publications of the Secretariat of the High Council of Urban and Architecture of Iran, Tehran.

[2] Mansour, Jahangir, 2007, laws and regulations related to province, city, town, village and municipality, Tehran, Didar publication.

[3] Ghorbani, Farajollah, 2007, Collections of Unity of the Supreme Administrative Court and the Administrative Court of Justice, Tehran, Ferdowsi Publications.

[4] Mansour Jahangir, 2005, Law of the Fourth Economic, Social and Cultural Development Program of the Islamic Republic of Iran (20052009), Tehran, Doran Publishing.

[5] Mansour, Jahangir, 2001, Law on City and Municipal Law, Tehran, Didar Publication.

[6] Plan and Budget Organization, 2016, Law of the Sixth Program of Economic, Social and Cultural Development of the Islamic Republic of Iran (2017-2021), Tehran, Planning and Budget Organization.

[7] Hojjati Ashrafi, Gholamreza, Constitution of the Islamic Republic, 2004, Tehran, Ganj Danesh.

[8] Hojjati Ashrafi, Gholamreza, Basic Law Collection - Civic, 1996, Tehran, Ganj Danesh Library.

[9] Plan and Budget Organization, 1970, Documentation of the First Economic, Social and Cultural Development Plan of the Islamic Republic of Iran (1993-1999), Tehran, Planning and Budget Organization.

[10] Program and Budget Organization, 1996, Documentation of the Second Economic, Social and Cultural Development Program of the Islamic Republic of Iran (1995-1999), Tehran, Planning and Budget Organization.

[11] Program and Budget Organization, 2001, Documentation of the Third Economic, Social and Cultural Development Program of the Islamic Republic of Iran (2000-2004), Tehran, Planning and Budget Organization.

[12] Program and Budget Organization, 2011, Documentation of the 5th Economic, Social and Cultural Development Program of the Islamic Republic of Iran (2011-2015), Tehran, Planning and Budget Organization.

[13] Badrian, Fakhreddin, 2004; Law - Rules of Procedure and Rules of the Administrative Court, Tehran, Arian Publishing. 